\title{
Lateral Flow Immunoassay for Rapid Diagnosis of Potato Blackleg Caused by Pectobacterium atrosepticum
}

\author{
I.V. Safenkova ${ }^{1}$, I.A. Zaitsev ${ }^{2}$, Yu.A. Varitsev ${ }^{2}$, \\ A.V. Zherdev ${ }^{1}$ and B.B. Dzantiev ${ }^{*}$ \\ ${ }^{1}$ A.N. Bach Institute of Biochemistry, Research Center of Biotechnology \\ of the Russian Academy of Sciences, Moscow, 119071 Russia \\ ${ }^{2}$ A.G. Lorch All-Russian Potato Research Institute, Kraskovo-1, Moscow region, 140051 Russia.
}

DOI: http://dx.doi.org/10.13005/bbra/1860

(Received: 28 September 2015; accepted: 03 November 2015)

\begin{abstract}
Potato blackleg and soft rot caused by Pectobacterium atrosepticum lead to significant yield losses. The early detection of $P$. atrosepticum is essential for healthy potato seed tubers. The aim of this study was to develop a method to rapidly detect $P$. atrosepticum based on the lateral flow immunoassay (LFIA) technique. Rabbit polyclonal antibodies specific to various strains of $P$. atrosepticum were obtained. Conjugates of these antibodies with gold nanoparticles averaging $20 \mathrm{~nm}$ in diameter were synthesized. Optimal concentrations of antibodies and conjugates deposited on membranes of the test strips were determined. The developed LFIA is suitable for analyzing potato tubers and leaves and has a visual detection limit of $2 \times 10^{5} \mathrm{cells} / \mathrm{mL}$ and a duration time of $10 \mathrm{~min}$. Simple, rapid preparation of samples consists of homogenization in extracting buffer. No cross-reactivities with other potato pathogens, such as Pectobacterium carotovorum subsp. carotovorum and Dickeya dianthicola, or saprophytes of healthy potato plants were detected. The assay was tested on 30 lots of potato tubers. The LFIA results were confirmed by ELISA (100\% concurrence) and PCR (87.5\% for positive samples and $95.5 \%$ for negative samples). Diagnosis of potato blackleg and soft rot by LFIA requires no equipment or training to perform, is cost effective and can be used in the field to monitor infection-causing $P$. atrosepticum.
\end{abstract}

Key words: Pectobacterium atrosepticum, gold nanoparticles, lateral flow immunoassay, potato diseases, potato blackleg, potato soft rot

\begin{abstract}
Pectobacterium atrosepticum (previously Erwinia atroseptica, Erwinia carotovora var. atroseptica) is a necrotrophic, Gram-negative, rod-shaped bacterium from the family Enterobacteriaceae that causes blackleg and soft rot diseases in the potato. Worldwide, $P$. atrosepticum is largely restricted to the potato, principally found in temperate regions, in contrast to other blackleg pathogens such as $P$. carotovorum subsp. carotovorum and Dickeya spp., and has a broad host range ${ }^{1}$. The economic losses caused by $P$. atrosepticum can be
\end{abstract}

\footnotetext{
* To whom all correspondence should be addressed. Tel./fax: +7-(495)-954-31-42;

E-mail: dzantiev@inbi.ras.ru
}

significant, depending on the value of the crop and the severity of the attack. The potential for economic losses makes $P$. atrosepticum one of the most threatening potato pathogens. The bacterium may localize in potato stems and tubers and live there for a considerable period in latent form, without pathological changes of the tissues. $P$. atrosepticum causes characteristic decay symptoms by producing massive amounts of enzymes that degrade a plant's cell walls and the middle lamella of leaves, stems, roots and tubers. Due to the lack of effective protocols for mass treatment, the main agro-technical approach is the rejection of infected plants. Given this, the detection of $P$. atrosepticum is essential to effectively protecting plants, especially seed 
potato $^{2-4}$. Thus, diagnosing infection is very important to the production of uncontaminated potato seed tubers ${ }^{3}$.

Currently, various techniques are applied for to diagnose plant infection, including immunochemical, genetic and biochemical techniques $^{5-8}$. However, these laboratory techniques are time-consuming and require complex equipment and skilled personnel. To be suitable for widespread monitoring of potato diseases in the field without special equipment or skills, diagnostics need to be simple, reliable, highly specific and sensitive. The lateral flow immunoassay (LFIA), also called the immunochromatographic assay, complies with all these requirements ${ }^{6,9,10}$. The application of antibodies makes LFIA sensitive and specific, while the lateral flow principle allows rapid analysis under out-oflaboratory conditions. All reactants are applied to the test strip before the assay, and contact between the strip and the test sample initiates specific interactions that yield a visible result: the presence or absence of coloration on certain areas of the strip. Sample preparation consists only of simple, rapid homogenization of the tissue in the extracting solution ${ }^{11-15}$.

Currently, the list of agricultural bacteria detected by commercially available LFIA systems is small. Similarly, developments described in the literature are limited ${ }^{6,10,14-16}$. Therefore, considering the number of serious bacterial infections known to affect crops and the associated losses ${ }^{17,}{ }^{18}$, the development of LFIA tests for bacterial phytopathogens is a high priority. Furthermore, to date, there is no LFIA method for detecting $P$. atrosepticum. The most commonly used methods for detecting it are modified PCR tests ${ }^{4,19,20}$.

The aim of this study was to develop an LFIA method to rapidly diagnose potato blackleg and soft rot caused by P. atrosepticum. The study includes characterization of the test components, LFIA development, its application in plant samples and comparison of the results obtained by the developed method and alternative analytical methods.

\section{MATERIALSANDMETHODS}

\section{Reagents and materials}

The study required the use of goat anti- rabbit IgG antibodies (Arista Biologicals, USA), peroxidase conjugate of streptavidin (Imtek, Russia), peroxidase conjugate of anti-rabbit antibodies (Medgamal, Russia), tris (hydroxymethyl) aminomethane (Tris), Tween 20, Triton X-100, 3,3',5,5'-tetramethylbenzidine dihydrochloride, sodium azide, biotinamidohexanoic acid $\mathrm{N}$-hydroxysuccinimide ester, protein A Sepharose CL-4B, Freund's adjuvant (Sigma, USA), chloroauric acid (Fluka, Germany), bovine serum albumin (BSA), sodium citrate, dimethylsulfoxide (MP Biomedicals, UK), GeneRuler $^{\mathrm{TM}} 100$ bp DNA Ladder (Thermo Fisher Scientific, USA), dNTP, Smart Taq DNA polymerase (Dialat, Russia), glycerol, $\mathrm{NaCl}, \mathrm{K}_{2} \mathrm{CO}_{3}$ (DiaM, Russia), yeast dextrose carbonate (YDC) agar, $\mathrm{Na}_{2} \mathrm{CO}_{3}, \mathrm{NaHCO}_{3}, \mathrm{KH}_{2} \mathrm{PO}_{4}$ and $\mathrm{KOH}$ (Khimmed, Russia). All chemicals were of analytical or chemical grade.

All solutions for the production of gold nanoparticles (GNP) and their conjugates were prepared using water deionized by a Milli-Q system (Millipore, USA). ELISA was carried out using 96well, transparent polystyrene microplates (Costar 9018; Corning Costar, USA). To manufacture test strip, membrane, components produced by Advanced Microdevices (India) were used, including working nitrocellulose membrane CNPC$12 \mu$, conjugate release matrix PT-R5, sample pad GFB-R4 (0.35), absorbent pad AP045 and laminates MT-1.

\section{Preparation of bacterial samples}

Pectobacterium atrosepticum (PaPa393, PaPa203-4 and PaPa204-3 isolates) and Dickeya dianthicola (D9, D17 and D33 isolates) were from the collection of phytopathogens of the AllRussian Research Institute of Phytopathology, Moscow, Russia. Pectobacterium atrosepticum (PaPa18077 isolate) and Pectobacterium carotovorum subsp. carotovorum (PaPa30168 isolate) were from the collection of phytopathogens of the Leibniz Institute DSMZGerman Collection of Microorganisms and Cell Cultures, Germany.

YDC agar was used to grow the target bacteria and saprophytic bacteria from leaf and tuber extracts ${ }^{21}$. The initial preparations were grown on the surface of the YDC agar medium for $48 \mathrm{~h}$ at $25-27^{\circ} \mathrm{C}$. The agar surface was flushed with sterile, phosphate-buffered saline (PBS; $50 \mathrm{mM}$ potassium 
phosphate, $\mathrm{pH} 7.4,0.14 \mathrm{M} \mathrm{NaCl}$ ) and pelleted three times by centrifugation $\left(10,000 \mathrm{~g}, 20 \mathrm{~min}, 4^{\circ} \mathrm{C}\right)$. The pellet was resuspended in PBS.

\section{Production of polyclonal antibodies}

The Pa393 isolate growing on YDC agar was used for immunization. Chinchilla rabbits (4-5 months old) were immunized according to a scheme that included two subcutaneous and four intramuscular injections with complete and incomplete Freund's adjuvant at weekly intervals. The immunization dose was $5 \times 10^{9}$ bacterial cells per animal. Blood was collected on days $7-12$ after the last injection. Titers of the obtained antisera determined by indirect ELISA were 1:250,000. Immunoglobulins were isolated from the antisera by affinity chromatography on protein ASepharose according to the manufacturer's instructions.

\section{Biotinylation of antibodies}

Biotinylation of antibodies was carried out as described by Hermanson ${ }^{22}$. The antibodies were dialyzed against a 1,000-fold volume of PBS for $4 \mathrm{~h}$ at $+4{ }^{\circ} \mathrm{C}$. Then, biotinamidohexanoic acid $\mathrm{N}$ hydroxysuccinimide ester $(10 \mathrm{mg} / \mathrm{mL}$, in dimethyl sulfoxide) was added to the antibodies in a 15:1 molar ratio. The mixture was incubated for $1 \mathrm{~h}$ at room temperature and then dialyzed against PBS. The preparation was stored at $+4{ }^{\circ} \mathrm{C}$.

\section{Enzyme-linked immunosorbent assay (ELISA)}

Immunoglobulins were immobilized from a $100-\mu \mathrm{L}$ volume in microplate wells at $+4{ }^{\circ} \mathrm{C}$ overnight, using solutions at a concentration of 2 $\mu \mathrm{g} / \mathrm{mL}$ in a PBS. The microplate was washed four times with a PBS with $0.05 \%$ Triton X-100 (PBST). Then, $50-\mu \mathrm{L}$ portions of bacteria solution (the concentrations varied from $10^{8} 500 \mathrm{cell} / \mathrm{mL}$ ) and antibodies-biotin conjugate solution $(4 \mu \mathrm{g} / \mathrm{mL})$ in PBST were added to the microplate wells. The microplate was incubated at $37^{\circ} \mathrm{C}$ for $60 \mathrm{~min}$ and washed as described above. Then, $100-\mu \mathrm{L}$ portions of the peroxidase conjugate of streptavidin (in the 1:5,000 dilution of the commercial preparation in PBST) were added and incubated at $37^{\circ} \mathrm{C}$ for 60 min. The microplate was repeatedly washed, and the peroxidase activity was determined. For this purpose, the substrate $(100 \mu \mathrm{L}$ of $0.4 \mathrm{mM} 3,3$ ',5,5'tetramethylbenzimidine solution in $40 \mathrm{mM}$ sodium citrate buffer, $\mathrm{pH} 4.0$, containing $3.0 \mathrm{mM}$ of $\mathrm{H}_{2} \mathrm{O}_{2}$ ) was added to each microplate well. After incubation at room temperature for $15 \mathrm{~min}$, the reaction was terminated by adding $1.0 \mu$ of $\mathrm{H}_{2} \mathrm{SO}_{4}(50 \mu \mathrm{L})$, and $\mathrm{OD}_{450}$ was measured.

\section{Synthesis of GNP}

One milliliter of $1 \% \mathrm{HAuCl}_{4}$ was added to $95 \mathrm{~mL}$ of deionized water, heated to boiling, and 4 $\mathrm{mL}$ of $1 \%$ sodium citrate was added on agitation ${ }^{23}$. The mixture was boiled for $25 \mathrm{~min}$ and then cooled and stored at $4-6{ }^{\circ} \mathrm{C}$.

\section{Transmission electron microscopy}

Preparations of colloidal gold particles or their conjugates were applied to 300-mesh grids (Pelco International, USA) coated with a support film of poly(vinyl formal) dissolved in chloroform. The images were obtained with a JEM CX-100 electron microscope (JEOL, Japan) operating at 80 $\mathrm{kV}$. The digital images were analyzed with the Image Tool program (University of Texas Health Science Center, San Antonio, USA).

\section{Synthesis of GNP-antibody conjugates}

The conjugates were synthesized as described in Safenkova et al., ${ }^{15}$. The antibodies were dialyzed against a 1,000-fold volume of 10 $\mathrm{mM}$ Tris-HCl, $\mathrm{pH} 9.0$, at $+4{ }^{\circ} \mathrm{C}$ for $12 \mathrm{~h}$. The $\mathrm{pH}$ of the GNP solution was adjusted to 9.0 with $0.2 \mathrm{M}$ of $\mathrm{K}_{2} \mathrm{CO}_{3}$. Then, the antibodies at concentrations of $20 \mu \mathrm{g} / \mathrm{mL}$ were added to the GNP solution. The mixture was stirred at room temperature for $60 \mathrm{~min}$, and then BSA was added to its final concentration of $0.25 \%$. The GNPs with immobilized antibodies were separated by centrifugation at $20,000 \mathrm{~g}$ for 30 min and resuspended in PBS containing $0.25 \%$ BSA, $0.25 \%$ Tween 20 and $1 \%$ saccharose. The conjugate was stored at $+4{ }^{\circ} \mathrm{C}$. For long-term storage, $\mathrm{NaN}_{3}$ was added to the sample to its final concentration of $0.02 \%$.

\section{Preparation of test strips}

Membrane compounds and multimembrane composite were prepared using approaches described in Safenkova et al. ${ }^{15}$. The GNP-antibody conjugate was deposited onto CNPC- $12 \mu$ membranes from a solution that had optical density equal to 10 at $\lambda=520 \mathrm{~nm}$. The conjugate load was $16 \mu \mathrm{L}$ per $\mathrm{cm}$ of strip width. The test zone was formed by IgG specific to $P$. atrosepticum, and the control zone was formed by goat anti-rabbit IgG. Both loading solutions were at concentrations of $1.0 \mathrm{mg} / \mathrm{mL}$ in PBS and were applied to $2 \mu \mathrm{L}$ per $\mathrm{cm}$ of strip width. After the assembly of membranes, the multi-membrane composite was cut into strips of $3.5 \mathrm{~mm}$ in width 
using an Index Cutter-1 (A-Point Technologies, USA) and hermetically packed into bags composed of laminated aluminum foil and containing silica gel as desiccant by using an FR-900 continuous band sealer (Wenzhou Dingli Packing Machinery, China). Cutting and packing were carried out at 20$22^{\circ} \mathrm{C}$ in a separate room with relative humidity of no more than $30 \%$.

\section{Preparation of potato seed material for testing}

The testing was performed on 30 lots that included up to 200 tubers each. Samples were obtained from various points in the Central Federal District of Russia. Samples 1-14 included 200 tubers each, samples 15-24 included 15 tubers each and samples 25-30 included 10 tubers each. Segments $(5 \times 5 \times 10 \mathrm{~mm})$ were cut from each tuber and placed in a $250-\mathrm{mL}$, conical flask. Then, $40 \mathrm{~mL}$ of autoclaved $50 \mathrm{mM}$ phosphate buffer with $\mathrm{pH} 7.0$ was added, and the resulting mixture was incubated at $5-10{ }^{\circ} \mathrm{C}$. The extract was filtered through white ribbon filter paper. The resulting filtrate was centrifuged at $10,000 \mathrm{~g}$ for $10 \mathrm{~min}$ at $5-7^{\circ} \mathrm{C}$. The pellet was resuspended in the PBS for ELISA and LFIA, and in sterile 0.01M Na-phosphate buffer with $\mathrm{pH} 7.0$ for PCR.

The leaf samples were triturated with a pestle in a porcelain mortar with $50 \mathrm{mM}$ of phosphate buffer (pH 7.0) and 20-fold excess. The extract was filtered, and all further operations were carried out as for tubers.

\section{LFIA}

The assay was performed at room temperature. The test strip was vertically submerged in the tested sample for $1.5 \mathrm{~min}$ and then taken out and placed on a horizontal surface. The qualitative results were estimated visually 10 min after the beginning of the assay. The visual limit of detection of the assay was defined as the minimum concentration giving rise to the band at the test zone. The color intensity was quantified by densitometry after completely air-drying the strip using a Reflekom portable photometric detector (Okta-Medika, Russia) according to Byzova et al., ${ }^{11}$. The registered value of 0.2 arbitrary (arb.) units of color intensity accorded with the threshold of reliable visual detection.

\section{ELISA using commercial kits}

The assay of $P$. atrosepticum was carried out using an ELISA Reagent Set (LOEWE Biochemica, Germany) according to the manufacturer's protocol. Optical absorbance of enzymatic reaction products was measured at 405 $\mathrm{nm}$.

\section{PCR analysis}

Bacterial DNA was isolated from plant extracts using Sample-GS kits (DNA Technology, Moscow). Thermal Cycler (Nyx Technik, USA) was used for the PCR. The analysis was performed with ECA1f (5'-CGGCATCATAAAAACACG-3') and ECA2r(5'-GCACACTTCATCCAGGGA-3') primers described in De Boer et al. ${ }^{24}$. The given primers are specific to the intergenic spacer of the ñhromosomal DNA of $P$. atrosepticum and give an amplification product with a size of $690 \mathrm{bp}$. The reaction mixture $(25 \mu \mathrm{L})$ included 20 pmol of each primer, $5 \mu \mathrm{L}$ of PCR buffer $5 \mathrm{x}, 1.5 \mathrm{mM}$ of $\mathrm{MgCl}_{2}, 200$ pmol of a dNTP mixture and 5 units of Smart Taq DNA polymerase. Total DNA of the Pa18077 strain of $P$. atrosepticum was used as a positive control, and total DNA of healthy potato leaves or tubers was used as a negative control.

To visualize the amplification results, electrophoresis in 1.5\% agarose gel with ethidium bromide added was performed as proposed by De Boer et al. ${ }^{24}$ using a horizontal camera from Helicon (Russia).

\section{RESULTSAND DISCUSSION}

\section{Characterization of antibodies}

Initially, the specificity of the polyclonal antibodies was tested. The antibody obtained at immunization with the Pa393 strain was tested by ELISA in reactions with closely related strains of P. atrosepticum and unrelated bacteria Dickeya (D9, D17 and D33 isolates).

Antibody characteristics were quite similar for various strains of $P$. atrosepticum (Fig. 1 , curves 1-3). The limit of detection (LOD) of $P$. atrosepticum was $1 \times 10^{5}$ cells $/ \mathrm{mL}$, which corresponds to the usual level of accumulation of the pathogen in infected potato tubers ${ }^{3}$. According to Czajkowski et al. ${ }^{3}$, bacterial densities in symptomatic tissues are often greater than $10^{6}$ cells/g. Specificity of the antibodies was confirmed by the low $\mathrm{OD}_{450}$ value the $D$. dianthicola strains (Fig. 1, curves 4-6).

\section{Producing GNPs and their conjugates with antibodies}

Transmission electron microscopy (TEM) 
was applied to characterize the synthesized GNP. It showed that their average diameter was $20 \pm 3$ $\mathrm{nm}$ and that the form factor (the maximum to minimum axis ratio) was $1.12 \pm 0.08$. The absorption maximum of the synthesized GNP was $520 \mathrm{~nm}$. These data suggest that preparation of GNP is monodisperse and does not contain aggregates. The GNPs were conjugated with the anti-P. atrosepticum antibodies. The absorption maximum of the conjugate was observed at $524 \mathrm{~nm}$ because immobilized antibodies caused a shift in the surface plasmon resonance of the GNPs. The conjugate concentrations were determined using $\mathrm{OD}_{520}$, taking into consideration that the immobilization of the antibodies led to an approximately $10 \%$ decrease in GNP absorption ${ }^{25}$.

\section{Developing the LFIA}

The polyvalence of the $P$. atrosepticum bacterium with a plurality of surface-exposed epitopes allowed us to develop the LFIA based on the methodological approaches that we proposed and successfully implemented for LFIAs for plant

Table 1. Results of ELISA, LFIA and PCR for potato tubers extracts

\begin{tabular}{|c|c|c|c|c|c|c|c|}
\hline \multirow[t]{2}{*}{ Sample } & \multirow[t]{2}{*}{ Variety } & \multicolumn{2}{|c|}{ ELISA } & \multicolumn{2}{|c|}{ LFIA } & \multirow{2}{*}{$\begin{array}{l}\text { PCR } \\
\text { Assay } \\
\text { result }\end{array}$} & \multirow{2}{*}{$\begin{array}{c}\text { P. atrosepticum } \\
\text { presence }\end{array}$} \\
\hline & & $\mathrm{OD}_{405}$ & $\begin{array}{l}\text { Assay } \\
\text { result }\end{array}$ & $\begin{array}{l}\text { Color intensity of } \\
\text { the test line, } \\
\text { (arb. units) }\end{array}$ & $\begin{array}{l}\text { Assay } \\
\text { result }\end{array}$ & & \\
\hline 1 & Impala & 0.11 & - & 0.00 & - & - & No \\
\hline 2 & Impala & 0.01 & - & 0.00 & - & - & No \\
\hline 3 & Kibits & 0.83 & + & 0.95 & + & + & Yes \\
\hline 4 & Saturna & 0.01 & - & 0.00 & - & - & No \\
\hline 5 & Phasan & 0.70 & + & 0.45 & + & + & Yes \\
\hline 6 & Bonus & 1.09 & + & 1.57 & + & + & Yes \\
\hline 7 & Hermes & 1.03 & + & 0.60 & + & + & Yes \\
\hline 8 & Monaliza & 0.01 & - & 0.00 & - & + & No/Yes \\
\hline 9 & Red Scarlet & 0.45 & + & 0.53 & + & + & Yes \\
\hline 10 & Salin & 1.14 & + & 1.53 & + & + & Yes \\
\hline 11 & Agatha & 0.01 & - & 0.00 & - & - & No \\
\hline 12 & Picasso & 0.01 & - & 0.00 & - & - & No \\
\hline 13 & Nevsky & 0.01 & - & 0.00 & - & - & No \\
\hline 14 & Impala & 0.51 & + & 0.30 & + & - & Yes/No \\
\hline 15 & Agria & 0.01 & - & 0.00 & - & - & No \\
\hline 16 & Ariel & 0.01 & - & 0.00 & - & - & No \\
\hline 17 & Ariel & 0.01 & - & 0.00 & - & - & No \\
\hline 18 & Arosa & 0.01 & - & 0.00 & - & - & No \\
\hline 19 & Belaroza & 0.01 & - & 0.00 & - & - & No \\
\hline 20 & Jelly & 0.01 & - & 0.00 & - & - & No \\
\hline 21 & Eurostar & 0.01 & - & 0.00 & - & - & No \\
\hline 22 & Zhukovsky early & 0.01 & - & 0.00 & - & - & No \\
\hline 23 & Courage & 0.01 & - & 0.00 & - & - & No \\
\hline 24 & Red Scarlet & 0.01 & - & 0.00 & - & - & No \\
\hline 25 & Lady Claire & 0.01 & - & 0.00 & - & - & No \\
\hline 26 & Unknown 1 & 0.01 & - & 0.00 & - & - & No \\
\hline 27 & Lady Claire & 0.01 & - & 0.00 & - & - & No \\
\hline 28 & Lady Claire & 0.01 & - & 0.00 & - & - & No \\
\hline 29 & Unknown 2 & 0.01 & - & 0.00 & - & - & No \\
\hline 30 & Lady Claire & 0.01 & - & 0.00 & - & - & No \\
\hline \multicolumn{2}{|c|}{ Negative control } & 0.10 & - & 0.00 & - & - & No \\
\hline \multicolumn{2}{|c|}{ Positive control } & 2.55 & + & 0.97 & + & + & Yes \\
\hline
\end{tabular}


viruses in our previous studies ${ }^{25,26}$. Based on the formation of immobilized antibody-antigen-labeled antibody complexes, the sandwich format LFIA was used. The LFIA was optimized by choosing concentrations of reactants (IgG and IgG-GNP conjugates) adequate to achieve maximum color intensity in both the test and control zones, as well as the lowest detection limit in the absence of background staining. The Materials and Methods section presents the selected conditions.

The maximum color intensity in the test and control zones was achieved upon deposition of antibodies from a solution at a concentration of $1.0 \mathrm{mg} / \mathrm{mL}$ (at a deposition density of $0.2 \mu \mathrm{L} / \mathrm{mm}$ ), and the intensity did not increase at higher concentrations. As a result, this concentration was selected for use in the optimum procedure. Antirabbit antibodies for control zones were applied to the membrane from a solution with a concentration of $0.5 \mathrm{mg} / \mathrm{mL}$ to give the maximum color intensity of the control line. The $\mathrm{OD}_{520}$ of the IgG-GNP conjugate solution used for the application in LFIA was 10.0 .

According to the digital recording data, the maximum color intensity in both zones occurred 10 minutes after sample contact with the test strip. Therefore, a 10-minute analysis time was chosen as optimal.

\section{Determining the detection limit of the developed LFIA}

Serial dilutions of $P$. atrosepticum in
PBST were tested using the developed LFIA. As shown in Fig. 2A, the color intensity of the test lines gradually grew with increasing analyte concentration in the sample (up to $10^{7}$ cells/mL). The coloration may be controlled quantitatively (Fig. 2B). In view of the threshold of reliable visual detection (0.2 arb. units of color intensity), $P$. atrosepticum can be reliably detected by LFIA at concentrations of $2 \times 10^{4}$ cells $/ \mathrm{mL}$ for Pa204-3, $3 \times$ $10^{4}$ cells $/ \mathrm{mL}$ for Pa393 and $2 \times 10^{5}$ cells $/ \mathrm{mL}$ for the Pa18077 strain (Fig. 2B). The LOD of LFIA is close

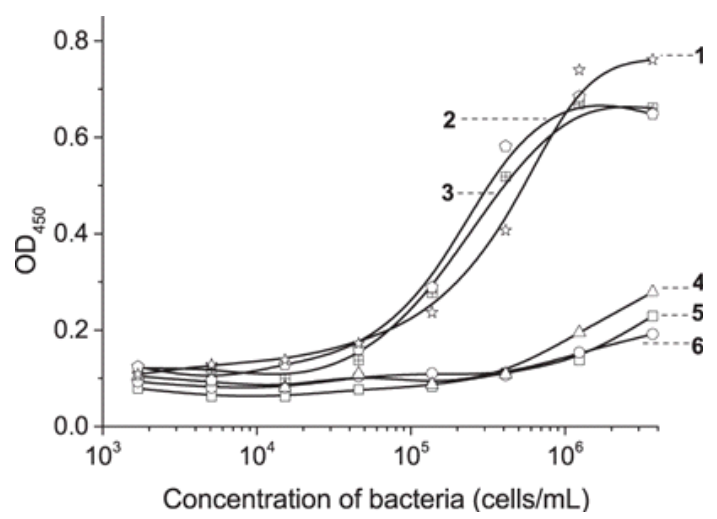

Fig. 1. Curves for sandwich ELISA with anti-P. atrosepticum antibody: plots of absorbance versus concentration of $P$. atrosepticum or D. dianthicola cells. Curves 1-6 accord to Pa393, Pa204-3 and Pa203-4 (P. atrosepticum); D9, D17 and D33 (D. dianthicola), respectively.
A

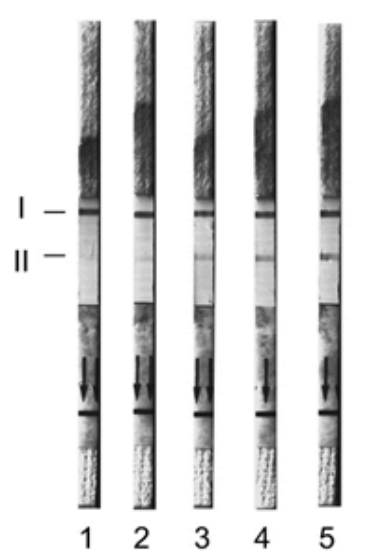

B

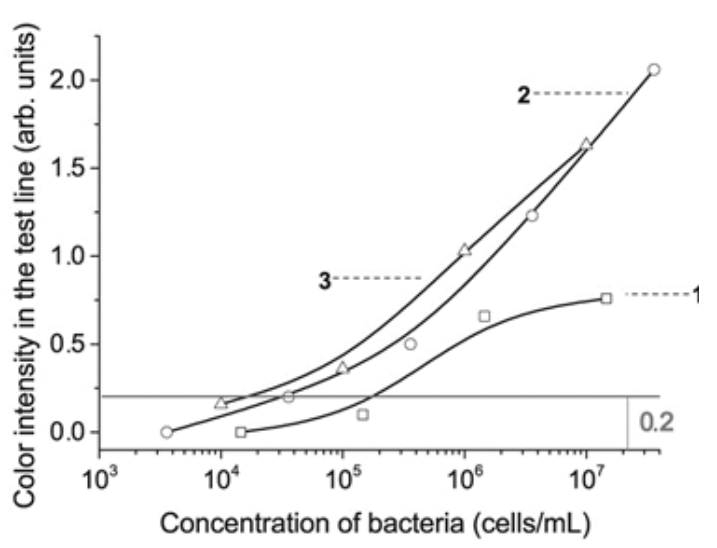

Fig. 2. LFIA of $P$. atrosepticum. A, test strips after the assay (I, the control zone; II, the test zone); $1-5$, the concentrations of $P$. atrosepticum (Pa393) in PBST are $3.6 \times 10^{3}$, $3.6 \times 10^{4}, 3.6 \times 10^{5}, 3.6 \times 10^{6}$ and $3.6 \times 10^{7}$ cell/mL. B, the color intensity in the test line (arb. units) versus the concentration of $P$. atrosepticum; curves 1-3 accord to Pa18077, Pa393 and Pa204-3, respectively 
in value to that obtained by ELISA.

To evaluate application of the developed LFIA to analysis of tubers and leaves, pure preparations of $P$. atrosepticum were added to extracts of healthy leaves and tubers. Figure 3 shows examples of such tests. The color intensity in the test lines was a bit higher after exposure to the leaf extracts and the tuber extracts than in the buffer solution.

Thus, the ranges of detection for $P$. atrosepticum strains by LFIA corresponded to the usual level of accumulation of the pathogen in infected potato tubers, which is greater than $10^{6}$ cells/g for symptomatic tissues ${ }^{3}$.

The study tested the specificity of the LFIA tests, showing that there is no cross-reactivity with the DSM 30168 strain of Pectobacterium carotovorum subsp. carotovorum. The tests did not give false positive results for the D9, D17 and D33 strains of Dickeya dianthicola, which cause potato and vegetable blackleg, or for saprophytes from healthy potato plant tubers and leaves isolated from pure cultures (five samples).

Validating test strips; comparing techniques for detecting $P$. atrosepticum

To examine the developed test systems, we analyzed 30 combined lots of seed potatoes (see Table 1) for the presence of P. atrosepticum. For this comparison, we used the developed LFIA test system, the commercial ELISA kit from LOEWE
(Germany) and the PCR assay. The P. atrosepticum was detected in tuber extracts in samples 3, 5-7, 9 10 (Table 1 ) by all methods, in sample 14 by ELISA and LFIA and in sample 8 by PCR only. Fig. 4A shows examples of test strips after the examination. Electrophoretic analysis of amplification products with ECA1f/ECA2r primers shows amplicons with a size of $690 \mathrm{bp}$ for seven samples infected by $P$. atrosepticum (Fig. 4B). The amplicons greater than or less than 690 base pairs indicate no presence of

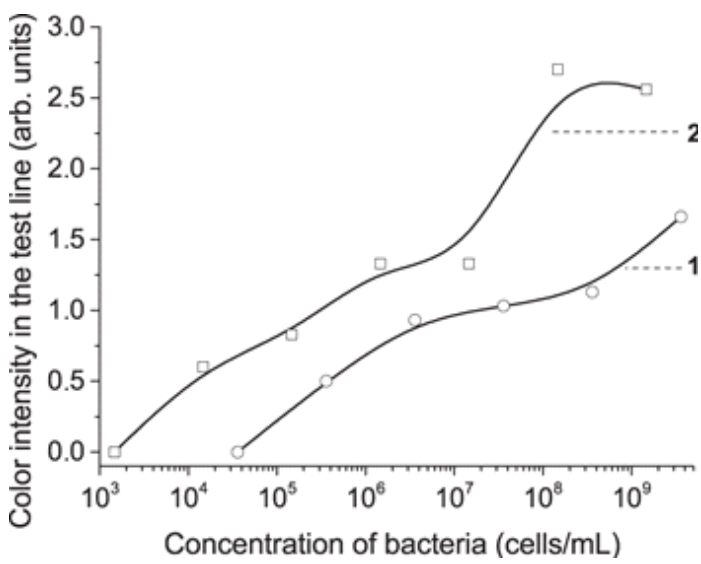

Fig. 3. Dependences of the color intensity of the test line of the LFIA system (arb. units) on the concentration of $P$. atrosepticum obtained for potato extracts; curve 1, strain Pa18077 in the leaf extract; curve 2, strain Pa393 in the tuber extract.
A

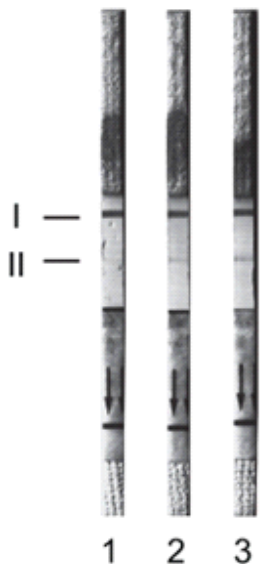

B

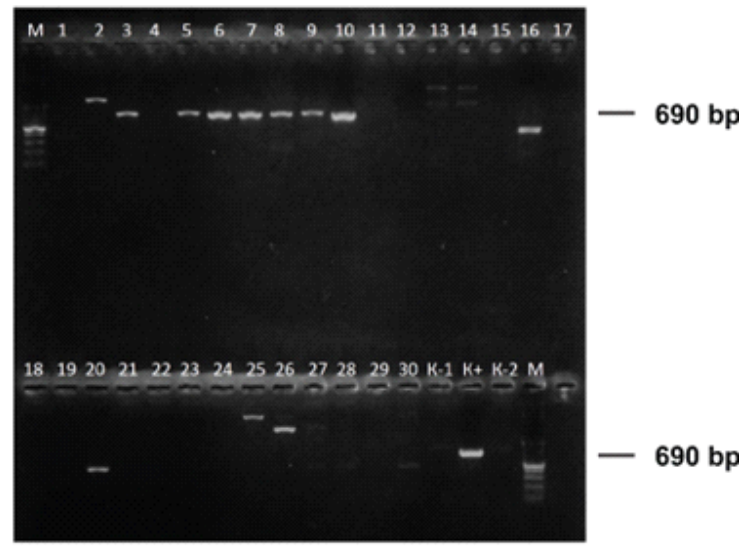

Fig. 4. Testing of seed material. A, an example of test strips after use in testing (I, the control zone; II, the test zone); 1-3, the numbers of samples are 4, 5 and 6, respectively. B, electrophoretic analysis of amplification products with ECA1f/ECA2r primers; M, GeneRuler ${ }^{\mathrm{TM}}$ from $100-1000$ bp; 1-30, potato samples; K-1, DNA from the tuber extract of healthy plants; K-2, DNA from the leaf extract of healthy plants; K+, total DNA of the Pa18077 strain 
P. atrosepticum in the sample.

The examination showed a 100\% overlap for LFIA and ELISA, for both positive and negative samples, and a high degree of overlap for LFIA and PCR, for both positive (87.5\%) and negative samples (95.5\%) (Table 1).

The results of this study show for the first time that using an LFIA to detect $P$. atrosepticum is feasible. This new LFIA can be used for rapid, sensitive control of bacterial cultures and symptomatic plant material and has a visual detection limit of $2 \times 10^{5}$ cells $/ \mathrm{mL}$ and an assay time of 10 minutes. Furthermore, this proposed method of monitoring $P$. atrosepticum is cost effective and can be used under field conditions.

\section{ACKNOWLEDGEMENTS}

The work was supported by the International Target Programme of the Eurasian Economic Community "Innovative Biotechnologies in 2011-2015” (Government Contract No. 14.M 04.11.0018, September 17, 2014).

\section{REFERENCES}

1. Ma, B., Hibbing, M.E., Kim, H.S., Reedy, R.M., Yedidia, I., Breuer, J., Breuer, J., Glasner, J.D., Perna, N.T., Kelman, A., Charkowski, A.O. Host range and molecular phylogenies of the soft rot enterobacterial genera Pectobacterium and Dickeya. Phytopathology 2007; 97:1150-1163.

2. Charkowski, A.O. Biology and control of Pectobacterium in potato. Am. J. Potato Res. 2015; 92:223-229.

3. Czajkowski, R., Perombelon, M.C.M., Jafra, S., Lojkowska. E., Potrykus, M., van der Wolf, J.M., Sledz, W. Detection, identification and differentiation of Pectobacterium and Dickeya species causing potato blackleg and tuber soft rot: a review. Ann. Appl. Biol. 2015; 166:18-38.

4. Humphris, S.N., Cahill, G., Elphinstone, J.G., Kelly, R., Parkinson, N.M., Pritchard, L., Toth, I.K., Saddler, G.S. Detection of the bacterial potato pathogens Pectobacterium and Dickeya spp. using conventional and real-time PCR. Methods Mol. Biol. (Clifton, NJ) 2015; 1302:116.

5. Charermroj, R., Himananto, O., Seepiban, C., Kumpoosiri, M., Warin, N., Gajanandana, O., Elliott, C.T., Karoonuthaisiri, N. Antibody array in a multiwell plate format for the sensitive and multiplexed detection of important plant pathogens. Anal. Chem. 2014; 86:7049-7056.

6. De Boer, S.H., Lopez, M.M. New growerfriendly methods for plant pathogen monitoring. Annu. Rev. Phytopathol., 2012; 50:197-218.

7. Lopez, M.M., Bertolini, E., Olmos, A., Caruso, P., Gorris, M.T., Llop, P., Penyalver, R., Cambra, M. Innovative tools for detection of plant pathogenic viruses and bacteria. International. Microbiol. 2003; 6:233-243.

8. Nezhad, A.S. Future of portable devices for plant pathogen diagnosis. Lab Chip 2014; 14: 2887-2904.

9. Dzantiev, B.B., Byzova, N.A., Urusov, A.E., Zherdev, A.V. Immunochromatographic methods in food analysis. TrAC-Trend Anal. Chem. 2014; 55: 81-93.

10. Shan, S., Lai, W., Xiong, Y., Wei, H., Xu, H. Novel strategies to enhance lateral flow immunoassay sensitivity for detecting foodborne pathogens. J. Agric. Food. Chem. 2015; 63:745753.

11. Byzova, N.A., Safenkova, I.V., Chirkov, S.N., Avdienko, V.G., Guseva, A.N., Mitrofanova, I.V., Zherdev, A.V., Dzantiev, B.B., Atabekov, J.G. Interaction of plum pox virus with specific colloidal gold-labeled antibodies and development of immunochromatographic assay of the virus. Biochemistry (Moscow) 2010, 75: 1393-1403.

12. Byzova, N.A., Safenkova, I.V., Chirkov, S.N., Zherdev, A.V., Blintsov, A.N., Dzantiev, B.B., Atabekov, I.G. Development of immunochromatographic test systems for express detection of plant viruses. Appl. Biochem. Microbiol. 2009; 45: 204-209.

13. Danks, C., Barker, I. On-site detection of plant pathogens using lateral-flow devices. EPPO Bulletin 2000; 30: 421-426.

14. Hodgetts, J., Karamura, G., Johnson, G., Hall, J., Perkins, K., Beed, F., Nakato, V., Grant, M., Studholme, D.J., Boonham, N., Smith, J. Development of a lateral flow device for in-field detection and evaluation of PCR-based diagnostic methods for Xanthomonas campestris pv. musacearum, the causal agent of banana xanthomonas wilt. Plant Pathol. 2015; 64:559567.

15. Safenkova, I.V., Zaitsev, I.A., Pankratova, G.K., Varitsev, Y.A., Zherdev, A.V., Dzantiev, B.B. Lateral flow immunoassay for rapid detection of potato ring rot caused by Clavibacter michiganensis subsp sepedonicus. Appl. Biochem. Microbiol. 2014; 50: 675-682.

16. Law, J.W.F., Ab Mutalib, N.S., Chan, K.G., Lee, L.H. Rapid methods for the detection of 
foodborne bacterial pathogens: principles, applications, advantages and limitations. Front Microbiol. 2015; 5: 770.

17. EPPO. EPPO A1 and A2 lists of Pests Recommended for Regulation as Quarantine Pests, EPPO Standard PM 1/2, in EPPO Standards: General Phytosanitary Measures EPPO. In Book EPPO A1 and A2 Lists of Pests Recommended for Regulation as Quarantine Pests, EPPO Standard PM 1/2, in EPPO Standards: General Phytosanitary Measures EPPO. Paris; 2014.

18. Narayanasamy, P. Diagnosis of Bacterial Diseases of Plants. In Microbial Plant Pathogens-Detection and Disease Diagnosis: Springer Netherlands; Houten; 2011: 233-246

19. Potrykus, M., Sledz, W., Golanowska, M., Slawiak, M., Binek, A., Motyka, A., Zoledowska, S., Czajkowski, R., Lojkowska, E. Simultaneous detection of major blackleg and soft rot bacterial pathogens in potato by multiplex polymerase chain reaction. Ann. Appl. Biol. 2014; 165: 474-487.

20. Slawiak, M., van Doorn, R., Szemes, M., Speksnijder, A., Waleron, M., van der Wolf, J.M., Lojkowska, E., Schoen, C.D. Multiplex detection and identification of bacterial pathogens causing potato blackleg and soft rot in Europe, using padlock probes. Ann. Appl. Biol. 2013; 163: 378-393.

21. Schaad, N.W., Jones, J.B., Chun, W. Laboratory Guide for Identification of Plant Pathogenic Bacteria. (Third Edition) St. Paul, MN. USA: APS Press; 2001.

22. Hermanson, G.T. Chapter 3 - The Reactions of Bioconjugation. In Bioconjugate Techniques (Third edition). Boston: Academic Press; 2013: 229-258.

23. Frens, G. Controlled nucleation for the regulation of the particle size in monodisperse gold suspensions. Nat. Phys. Sci. 1973; 241: 20-22.

24. De Boer, S.H., Ward, L.J. PCR detection of Erwinia carotovora subsp. atroseptica associated with potato tissue. Phytopathology 1995; 85: 854-858.

25. Safenkova, I.V., Zherdev, A.V., Dzantiev, B.B. Factors influencing the detection limit of the lateral-flow sandwich immunoassay: a case study with potato virus X. Anal. Bioanal. Chem. 2012; 403: 1595-1605.

26. Safenkova, I.V., Zherdev, A.V., Dzantiev, B.B. Correlation between the composition of multivalent antibody conjugates with colloidal gold nanoparticles and their affinity. J. Immunol. Methods. 2010; 357:17-25. 